\title{
Mesophotic Ecosystems: The Link between Shallow and Deep-Sea Habitats
}

\author{
Gal Eyal 1,2,*(D) and Hudson T. Pinheiro ${ }^{3, *(\mathbb{D})}$ \\ 1 ARC Centre of Excellence for Coral Reef Studies, School of Biological Sciences, The University of \\ Queensland, St. Lucia, QLD 4072, Australia \\ 2 The Mina \& Everard Goodman Faculty of Life Sciences, Bar-Ilan University, Ramat Gan 5290002, Israel \\ 3 Department of Ichthyology, California Academy of Sciences, San Francisco, CA 94118, USA \\ * Correspondence: gal4596@gmail.com (G.E.); htpinheiro@gmail.com (H.T.P.)
}

Received: 26 October 2020; Accepted: 27 October 2020; Published: 28 October 2020

\begin{abstract}
Mesophotic ecosystems (MEs) are characterized by the presence of light-dependent organisms, found at depths ranging from $\sim 30$ to $150 \mathrm{~m}$ in temperate, subtropical and tropical regions. These communities occasionally create massive reef structures with diverse but characteristic morphologies, which serve as the framework builders of those ecosystems. In many localities, MEs are physically linked with shallow and deep-sea habitats, and while taxa from both environments share this space, a unique and endemic biodiversity is also found. The main MEs studied to date are the mesophotic coral ecosystems (MCEs) and the temperate mesophotic ecosystems (TMEs), which have received increased attention during the last decade. As shallow coral reef ecosystems are among the most threatened habitats on Earth, the potential of MEs to act as refugia and contribute to the resilience of the whole ecosystem has been a subject of scrutiny. New technologies and methods have become more available to study these deeper parts of the reef ecosystems, yielding many new discoveries. However, basic gaps in knowledge remain in our scientific understanding of the global diversity of MEs, limiting our ability to recognize biogeographic patterns and to make educated decisions for the management and conservation of these ecosystems.
\end{abstract}

Keywords: coral reefs; deep reefs; marine habitats; vertebrates; invertebrates; community dynamics; light; biodiversity; ecology; natural history; refuge; technical diving

\section{Introduction}

Shallow marine habitats occupying photic-zone areas over a large latitudinal gradient, from tropical to temperate waters, are part of the most productive and diverse ecosystems. For example, tropical coral reefs are among the most diverse habitats on the globe [1,2], demonstrating high efficiency in the retention and recycling of carbon and nutrients, which contribute to the productivity of the ecosystem [3,4]. Compared to shallow habitats, mesophotic coral ecosystems (MCEs) and temperate mesophotic ecosystems (TMEs) have received little research attention [5,6]. Although those mesophotic ecosystems (MEs) represent approximately $60-80 \%$ of the potential reef habitat area worldwide $[7,8]$, knowledge of their distribution, biodiversity, community composition and ecological processes remains limited $[6,9,10]$.

The criteria for defining MEs is poorly established and still in question. Scientists usually follow arbitrary depth ranges without geomorphological or biological rationale. For modern MCEs, the common definition is based on physical water depth, involving light-dependent coral ecosystems from 30 to $150 \mathrm{~m}$ in tropical and subtropical regions [11]. Subdivisions of upper MCEs and lower MCEs are also common [12] and although a general global $60 \mathrm{~m}$ community break is suggested [13], there have been a few attempts to define those zones by light levels $[14,15]$. Recently, scientists have also started 
to use fixed depth ranges to study temperate ecosystems [5], investigating from upper TMEs between 50 and $60 \mathrm{~m}$ to lower TMEs at 100-150 m [16,17]. A few ecological and biological studies have also tried to explain the boundaries between shallow and mesophotic reefs by using light-dependent coral assemblages and light levels to define the zonation along the depth gradient [13-15,18].

Geologists usually use the mesophotic definition to characterize assemblages of fossil platy corals, where estimates of surface photosynthetic active radiation (PAR) between $1 \%$ and $20 \%$ are found [19-22]. Furthermore, in some cases, further zoning is used to define the depth gradient, including "euphotic" (20-100\%; good light and, in open seas, commonly with high wave energy), "mesophotic" (5-20\% PAR; sufficient light for coral growth, commonly below normal wave base), "oligophotic" (1-5\%; sufficient light for coralline red algal growth), "disphotic" (0-1\%; absence of sufficient light for photosynthesis) and "aphotic" (absence of light) zones [20-23].

Biodiversity studies conducted to date have revealed diverse coral and fish communities in MCEs $[12,24,25]$. The highest diversity levels have been reported for regions such as the Coral Triangle [26,27] and the Hawaiian Archipelago [28]. Unique communities have been reported [29], and the discovery rate for new fish species is currently around 2.0 species per hour in unexplored lower MCEs of the Pacific and Atlantic Oceans [26]. However, there is a strong geographic bias for MCE research, and the locations of existing MCE habitats are not related to the locations where most research has been conducted to date [8].

Moreover, despite a widely reported trend of a decrease in species richness along the depth gradient [12,30-33], recent contributions have suggested that extensive fish species turnover (species replacement), instead of purely nestedness (species loss), characterize this spatial gradient from shallow to mesophotic depths [26,29]. Historically, however, MCEs have been considered more stable ecosystems compared to shallow reefs [34-37], and, due to the attenuation of climate change stressors (tropical storms and rising sea temperature) with depth, they were suggested to provide refuge for shallow water species - a concept known as the "Deep Reef Refuge Hypothesis" (DRRH) [38-40].

Concluding, although the number of publications on the biodiversity and community structure of MEs compared to that on any other theme of mesophotic research is high [5,41], there is an urgent need to increase the scientific knowledge on the diversity of fish, corals and other associated taxa in mesophotic ecosystems, and how they relate to shallow and deep-sea ecosystems. This Special Issue aims to promote scientific knowledge on the diversity of MEs, a step to a better understanding of biogeographic patterns, and also to make educated decisions for the management and conservation of these ecosystems.

Author Contributions: Both authors contributed equally to all aspect of this editorial paper. All authors have read and agreed to the published version of the manuscript.

Funding: This research received funding from the European Union's Horizon 2020 research and innovation program under the Marie Skłodowska-Curie grant agreement No. 796025.

Acknowledgments: We thank the Editorial staff of Diversity for their collaboration on this Special Issue (more information and submission guidelines can be found at https://www.mdpi.com/journal/diversity/special_issues/ Mesophotic_Ecosystems). H.T.P thanks the Hope for Reefs initiative of the California Academy of Sciences for funding and a fellowship.

Conflicts of Interest: The authors declare no conflict of interest.

\section{References}

1. Stehli, F.G.; Wells, J.W. Diversity and Age Patterns in Hermatypic Corals. Syst. Zool. 1971, 20, 115. [CrossRef]

2. Bellwood, D.R. Regional-Scale Assembly Rules and Biodiversity of Coral Reefs. Science 2001, 292, 1532-1535. [CrossRef]

3. Odum, H.T.; Odum, E.P. Trophic Structure and Productivity of a Windward Coral Reef Community on Eniwetok Atoll. Ecol. Monogr. 1955, 25, 291-320. [CrossRef]

4. Hatcher, B.G. Coral reef primary productivity. A hierarchy of pattern and process. Trends Ecol. Evol. 1990, 5, 149-155. [CrossRef] 
5. Turner, J.A.; Andradi-Brown, D.A.; Gori, A.; Bongaerts, P.; Burdett, H.L.; Ferrier-Pagès, C.; Voolstra, C.R.; Weinstein, D.K.; Bridge, T.C.; Costantini, F.; et al. Key questions for research and conservation of mesophotic coral ecosystems and temperate mesophotic ecosystems. In Mesophotic Coral Ecosystems; Loya, Y., Puglise, K.A., Bridge, T.C.L., Eds.; Springer: Cham, Switzerland, 2019; pp. 989-1003.

6. Turner, J.A.; Babcock, R.C.; Hovey, R.K.; Kendrick, G.A. Deep thinking: A systematic review of mesophotic coral ecosystems. ICES J. Mar. Sci. 2017, 74, 2309-2320. [CrossRef]

7. Eyal, G.; Tamir, R.; Kramer, N.; Eyal-Shaham, L.; Loya, Y. The red sea: Israel. In Mesophotic Coral Ecosystems; Loya, Y., Puglise, K.A., Bridge, T.C.L., Eds.; Springer: Cham, Switzerland, 2019; pp. 199-214.

8. Pyle, R.L.; Copus, J.M. Mesophotic coral ecosystems: Introduction and overview. In Mesophotic Coral Ecosystems; Loya, Y., Puglise, K.A., Bridge, T.C.L., Eds.; Springer: Cham, Switzerland, 2019; pp. 3-27.

9. Kahng, S.E.; Copus, J.M.; Wagner, D. Recent advances in the ecology of mesophotic coral ecosystems (MCEs). Curr. Opin. Environ. Sustain. 2014, 7, 72-81. [CrossRef]

10. Loya, Y.; Eyal, G.; Treibitz, T.; Lesser, M.P.; Appeldoorn, R. Theme section on mesophotic coral ecosystems: Advances in knowledge and future perspectives. Coral Reefs 2016, 35, 1-9. [CrossRef]

11. Hinderstein, L.M.; Marr, J.C.A.; Martinez, F.A.; Dowgiallo, M.J.; Puglise, K.A.; Pyle, R.L.; Zawada, D.G.; Appeldoorn, R. Theme section on "Mesophotic Coral Ecosystems: Characterization, Ecology, and Management". Coral Reefs 2010, 29, 247-251. [CrossRef]

12. Pinheiro, H.T.; Goodbody-Gringley, G.; Jessup, M.E.; Shepherd, B.; Chequer, A.D.; Rocha, L.A. Upper and lower mesophotic coral reef fish communities evaluated by underwater visual censuses in two Caribbean locations. Coral Reefs 2016, 35, 139-151. [CrossRef]

13. Lesser, M.P.; Slattery, M.; Laverick, J.H.; Macartney, K.J.; Bridge, T.C. Global community breaks at $60 \mathrm{~m}$ on mesophotic coral reefs. Glob. Ecol. Biogeogr. 2019, 28, 1403-1416. [CrossRef]

14. Laverick, J.H.; Tamir, R.; Eyal, G.; Loya, Y. 2020 A generalized light-driven model of community transitions along coral reef depth gradients. Glob. Ecol. Biogeogr. 2020, 29, 1554-1564. [CrossRef]

15. Tamir, R.; Eyal, G.; Kramer, N.; Laverick, J.H.; Loya, Y. Light environment drives the shallow-to-mesophotic coral community transition. Ecosphere 2019, 10. [CrossRef]

16. Bo, M.; Bertolino, M.; Borghini, M.; Castellano, M.; Harriague, A.C.; Di Camillo, C.G.; Gasparini, G.; Misic, C.; Povero, P.; Pusceddu, A.; et al. Characteristics of the Mesophotic Megabenthic Assemblages of the Vercelli Seamount (North Tyrrhenian Sea). PLoS ONE 2011, 6, e16357. [CrossRef] [PubMed]

17. Chimienti, G.; Mastrototaro, F.; D'Onghia, G. Mesophotic and Deep-Sea Vulnerable Coral Habitats of the Mediterranean Sea: Overview and Conservation Perspectives. In The Benthos Zone; Soto, L., Ed.; IntechOpen: London, UK, 2019; pp. 1-20.

18. Laverick, J.H.; Andradi-Brown, D.A.; Rogers, A.D. Using light-dependent scleractinia to define the upper boundary of mesophotic coral ecosystems on the reefs of Utila, Honduras. PLoS ONE 2017, 12, e0183075. [CrossRef]

19. Rosen, B.; Aillud, G.; Bosellini, F.; Clack, N.J.; Insalaco, E.; Valldeperas, F.; Wilson, M. Platy coral assemblages: 200 million years of functional stability in response to the limiting effects of light and turbidity. In Proceedings of the Ninth International Coral Reefs Symposium, Bali, Indonesia, 23-27 October 2000; pp. 255-264.

20. Pomar, L.; Baceta, J.I.; Hallock, P.; Mateu-Vicens, G.; Basso, D. Reef building and carbonate production modes in the west-central Tethys during the Cenozoic. Mar. Pet. Geol. 2017, 83, 261-304. [CrossRef]

21. Renema, W. Large Benthic Foraminifera in Low-Light Environments. In Mesophotic Coral Ecosystems; Loya, Y., Puglise, K.A., Bridge, T.C.L., Eds.; Springer: Cham, Switzerland, 2019; pp. 553-561.

22. Kołodziej, B.; Bucur, I.I. An Early Cretaceous mesophotic coral ecosystem built by platy corals (middle Aptian, Southern Carpathians, Romania). Cretac. Res. 2020, 109, 104374. [CrossRef]

23. Pomar, L. Types of carbonate platforms: A genetic approach. Basin Res. 2001, 13, 313-334. [CrossRef]

24. Pinheiro, H.T.; Mazzei, E.; Moura, R.L.; Amado-Filho, G.M.; Carvalho-Filho, A.; Braga, A.C.; Costa, P.A.S.; Ferreira, B.P.; Ferreira, C.E.L.; Floeter, S.R.; et al. Fish Biodiversity of the Vitória-Trindade Seamount Chain, Southwestern Atlantic: An Updated Database. PLoS ONE 2015, 10, e0118180. [CrossRef]

25. Simon, T.; Pinheiro, H.T.; Moura, R.L.; Carvalho-Filho, A.; Rocha, L.A.; Martins, A.S.; Mazzei, E.; Francini-Filho, R.B.; Amado-Filho, G.M.; Joyeux, J.-C. Mesophotic fishes of the Abrolhos Shelf, the largest reef ecosystem in the South Atlantic. J. Fish Biol. 2016, 89, 990-1001. [CrossRef] 
26. Pinheiro, H.T.; Shepherd, B.; Castillo, C.; Abesamis, R.A.; Copus, J.M.; Pyle, R.L.; Greene, B.D.; Coleman, R.R.; Whitton, R.K.; Thillainath, E.; et al. Deep reef fishes in the world's epicenter of marine biodiversity. Coral Reefs 2019, 38, 985-995. [CrossRef]

27. Andradi-Brown, D.A.; Beer, A.J.; Colin, L.; Head, C.E.; Hidayat, N.I.; Lindfield, S.J.; Mitchell, C.R.; Pada, D.N.; Piesinger, N.M.; Ahmadia, G.N. Highly Diverse Mesophotic Reef Fish Communities in Raja Ampat, West Papua. bioRxiv 2020, 640490. [CrossRef]

28. Pyle, R.L.; Boland, R.; Bolick, H.; Bowen, B.W.; Bradley, C.J.; Kane, C.; Kosaki, R.K.; Langston, R.; Longenecker, K.; Montgomery, A.; et al. A comprehensive investigation of mesophotic coral ecosystems in the Hawaiian Archipelago. PeerJ 2016, 4, e2475. [CrossRef] [PubMed]

29. Rocha, L.A.; Pinheiro, H.T.; Shepherd, B.; Papastamatiou, Y.P.; Luiz, O.J.; Pyle, R.L.; Bongaerts, P. Mesophotic coral ecosystems are threatened and ecologically distinct from shallow water reefs. Science 2018, 361, 281-284. [CrossRef] [PubMed]

30. Feitoza, B.M.; Rosa, R.S.; Rocha, L.A. Ecology and zoogeography of deep-reef fishes in northeastern Brazil. Bull. Mar. Sci. 2005, 76, 725-742.

31. Bejarano, I.; Appeldoorn, R.S.; Németh, M. Fishes associated with mesophotic coral ecosystems in La Parguera, Puerto Rico. Coral Reefs 2014, 33, 313-328. [CrossRef]

32. Andradi-Brown, D.A.; Macaya-Solis, C.; Exton, D.A.; Gress, E.; Wright, G.; Rogers, A.D. Assessing Caribbean Shallow and Mesophotic Reef Fish Communities Using Baited-Remote Underwater Video (BRUV) and Diver-Operated Video (DOV) Survey Techniques. PLoS ONE 2016, 11, e0168235. [CrossRef]

33. Coleman, R.R.; Copus, J.M.; Coffey, D.M.; Whitton, R.K.; Bowen, B.W. Shifting reef fish assemblages along a depth gradient in Pohnpei, Micronesia. PeerJ 2018, 6, e4650. [CrossRef]

34. Lesser, M.P.; Slattery, M.; Leichter, J.J. Ecology of mesophotic coral reefs. J. Exp. Mar. Biol. Ecol. 2009, 375, 1-8. [CrossRef]

35. Bridge, T.C.; Done, T.; Friedman, A.; Beaman, R.; Williams, S.; Pizarro, O.; Webster, J. Variability in mesophotic coral reef communities along the Great Barrier Reef, Australia. Mar. Ecol. Prog. Ser. 2011, 428, 63-75. [CrossRef]

36. Slattery, M.; Lesser, M.; A Brazeau, D.; Stokes, M.; Leichter, J.J. Connectivity and stability of mesophotic coral reefs. J. Exp. Mar. Biol. Ecol. 2011, 408, 32-41. [CrossRef]

37. Reardon, S. Hurricane Maria's wrath leaves clues to coral reefs' future. Nat. Cell Biol. 2018, 560, 421-422. [CrossRef]

38. Glynn, P.W. Coral reef bleaching: Facts, hypotheses and implications. Glob. Chang. Biol. 1996, 2, 495-509. [CrossRef]

39. Bongaerts, P.; Ridgway, T.; Sampayo, E.M.; Hoegh-Guldberg, O. Assessing the 'deep reef refugia' hypothesis: Focus on Caribbean reefs. Coral Reefs 2010, 29, 309-327. [CrossRef]

40. Bongaerts, P.; Smith, T.B. Beyond the "Deep Reef Refuge" Hypothesis: A Conceptual Framework to Characterize Persistence at Depth. In Mesophotic Coral Ecosystems; Loya, Y., Puglise, K.A., Bridge, T.C.L., Eds.; Springer: Cham, Switzerland, 2019; pp. 881-895.

41. Bongaerts, P.; Perez-Rosales, G.; Radice, V.Z.; Eyal, G.; Gori, A.; Gress, E.; Hammerman, N.M.; Hernandez-Agreda, A.; Laverick, J.H.; Muir, P.R.; et al. Mesophotic.org: A repository for scientific information on mesophotic ecosystems. Database 2019, 2019. [CrossRef] [PubMed]

Publisher's Note: MDPI stays neutral with regard to jurisdictional claims in published maps and institutional affiliations.

(C) 2020 by the authors. Licensee MDPI, Basel, Switzerland. This article is an open access article distributed under the terms and conditions of the Creative Commons Attribution (CC BY) license (http://creativecommons.org/licenses/by/4.0/). 